NUCLEAR POWER

\section{Perm any Two from Three}

The first result of the Ministry of Technology's determination to reorganize the nuclear power industry emerged this week with the announcement of the formation of a new company to design and build nuclear power stations. The ministry has decided that there shall be two such companies in place of the three consortia which exist at present. The company announced this week will be controlled by the three companies which made up the Nuclear Design and Construction consortium, and there will also be a shareholding by the Industrial Reorganization Corporation and, for the time being at least, by the Atomic Energy Authority. The most important holders of stock in the new company will be Babcock and Wilcox and English Electric, each of which will take 25 per cent of the share capital. Taylor Woodrow, the civil engineers, will take 4 per cent, and the IRC will hold 26 per cent. The remaining 20 per cent will be held by the Atomic Energy Authority, although the intention is that this share will eventually be sold to the nuclear fuel company which also forms part of the reorganization plan.

The announcement means that the NDC consortium will now be not a consortium but a company, with its shares owned by the same firms which originally formed the consortium. In order to fit in with the ministry's plans, the other two consortia, Atomic Power Constructions Ltd, and the Nuclear Power Group, will have to be boiled down into a single company, with its shares owned by at least some of the companies which now make up the consortia. On the electrical side, the mergers are already well under way, and it seems likely that the crucial issue will be to arrange agreement on the rationalization of the boilermaking side of the industry. Three boilermakers are involved-Clarke Chapman, John Thompson, and International Combustion. The three companies are already negotiating, and the expectation is that the talks will lead to the formation of a single boilermaking group to form the core of the second design and construction company. It would then be possible for the combined boilermaking company to come together with the AEA and the IRC to form the second company.

A smaller shareholding in the second company might perhaps be found for Fairey Engineering, which at the

PUGWASH, 1968

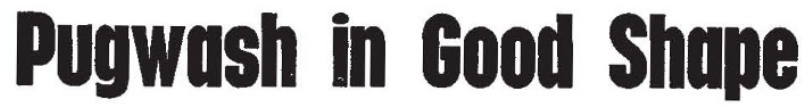

from our own Correspondent

Nice, September 16

JUDGING from the atmosphere among the old hands at this year's Pugwash Conference, the eighteenth, Pugwash has generated a new lease of life. For one thing, its finances are now on a sound footing. In the past year, national groups have guaranteed annual contributions well above the previous shoestring level. The Russian and American groups, for example, have doubled their contributions, and although this system in part relies indirectly on money from national governments, it has not yet compromised the organization's independence. It has meant, however, that moment forms part of APC. But there is no compelling reason for the inclusion of electrical companies, if the Central Electricity Generating Board is serious in its intention to move away from turnkey contracting. The new company could easily contract work out to electrical companies, and this may well be the pattern decided on. It is also improbable that civil engineers will take a large holding in the new company.

There are still some uncertainties. The IRC intends that the 20 per cent shareholding taken by the AEA will be sold to the fuel company, but the AEA gives the impression that it would be interested in retaining a share of some sort in the company. The IRC intends to dispose of its shareholding to "one or more of the other shareholders", and says that it is not the intention that the AEA should be given a chance of buying these. Thus, if all goes as the IRC intends, the AEA will be left with no shareholding at all in the two companies.

The other doubt is about the strength of the new company. For one thing, it is doubtful whether its capital value will be large enough to give it a proper backing in world markets. The IRC will not say exactly what it is going to pay for its 26 per cent share of the equity (and indeed this is uncertain until the full details of the company are worked out) but confirms that it would be around $£ 1$ million. This means that the total capital value of the company will be less than $£ 4$ million, little enough when dealing with international contracts worth perhaps $£ 80$ million, in competition with General Electric (USA) and Westinghouse. The other doubt arises because the new company has very little work to do; much will depend on whether it wins the contract for the nuclear power station at Hartlepools. Fortunately, this does seem likely to happen. The CEGB has agreed to let NDC announce that it is negotiating design and construction details for the Hartlepools station. Although this does not mean that NDC - the new company, in fact-has the Hartlepool contract sewn up, it does suggest that it has by far the best chance of winning it.

As soon as the new company is set up, it will be free to recruit staff from the AEA. Because it is the first in the field, the new company may well gain an advantage. The IRC is quite unrepentant about this, and goes as far as to hope that it will encourage the other companies to agree quickly to merger terms. An announcement can be expected quite soon.
Professor J. Rotblat has been able to forget the thoughts he had of resigning from the secretary-generalship. Furthermore, Pugwash can now afford a full-time executive secretary, Dr C. F. Barnaby, and central offices in London as the result of the generosity of an American supporter, Mr W. Schwarz of Chicago.

Except for Dr T. Nemec, the secretary of the Czechoslovak Pugwash group who has been travelling abroad this summer, the Czechoslovaks invited were not at Nice to appreciate the support the Pugwash conference provided for them. One conjecture was that they had absented themselves through fear of worsening their 